\title{
PROTOZOOSIS CAUSED BY Vairimorpha necatrix (MICROSPORIDA, NOSEMATIDAE) IN LARVAE OF Spodoptera frugiperda (LEPIDOPTERA, NOCTUIDAE).
}

\author{
Prafulbala N. Patel ${ }^{1}$ \\ Mohamed E. M. Habib ${ }^{1}$
}

\begin{abstract}
Vairimorpha necatrix was detected among laboratory cultured and field collected Spodoptera frugiperda larvae. Weak infections were not always fatal. In the case of fatal infections among diseased larvae, white patches were formed by agglomerations of adipose tissue beneath the transparent integument.

The mid-gut of $\mathrm{S}$. frugiperda larvae presented the first site of histological alterations caused by $\mathbf{V}$. necatrix. The migration of the pathogen, probably occured in the form of agglomerations, from the epithelial cells to the body cavity. Adipose tissue appears to be the principal site for the pathogen development. The nerve ganglia, muscle fibres and epidermis also presented histological alterations due to the pathogen propagation.
\end{abstract}

\section{INTRODUCTION}

Nosema necatrix, like some other species of the genus, is basically pathogenic in relation to some lepidopterous larvae. Nosema and Thelohania were considered as responsible for a microsporidiosis in larvae of the armyworm, Pseudaletia unipunctata (Haworth). Such a disease was previously recorded by Tanada and Chang (1962). Subsequently, Kramer (1965) named the two pathogens as Nosema necatrix and Thelohania diazoma and described their life cycle, mentioning that both of them occurred in the same host organ. Madox (1968) suggested that these two agents represented a single dimorphic species and that the dimorphism depends upon the temperature conditions. Pilley (1976) investigating the life cycle of such a pathogen in another host,Spodoptera exempta, confirmed the existence of dimorphism and placed this microorganism in a new genus, Vairimorpha.

The purpose of the present study is to demonstrate some external symptoms and histopathological effects caused by $V$. necatrix in Spodoptera frugiperda larvae. The disease was initially detected under laboratory conditions and later in corn fields (State of São Paulo). In many cases, the larvae suffered mixed infections caused by NPV (Nuclear Polyhedrosis Virus) and V. necatrix.

1 Departamento de Zoologia, UNICAMP, 13.100, Campinas, SP. 


\section{MATERIAL AND METHODS}

For the symptomatological descriptions, parameters indicated by Steinhaus (1963), Habib (1978a) and Patel (1981) were adopted. For the histopathological examinations, basic histological techniques and optical microscopy were utilized. Sections (6-8 microns thick) stained by haematoxylin and counter stained by eosin were examined.

\section{RESULTS AND DISCUSSION}

\section{Symptomatology:}

The diseased larvae during the initial phase of infection did not present any evident or clear symptoms. Light pink coloration on the ventral side of the body, specially between the sternites, lack of appetite and slight flaccidity were the first signs observed. The highly infected larvae almost stopped feeding and the light pink coloration became more pronounced. The flaccidity became more intensified leading to death. The dead larvae became black in color, revealing accelerated alterations of the body tissues, but always without emitting odour and the cuticle remained intact.

Weak infections were not always fatal. In the case of fatal infections, the larvae became turgid, the coloration continued to be lightly pink and white patches beneath the transparent integument began to appear. These patches are agglomerations of infected adipose tissue, and they were more evident on the ventral side of the body wall. Our observations coincide with the general symptomatological description given by Steinhaus (1963) for microsporidial infections. The surviving infected larvae were able to pupate normally but resulted in adults both smaller in size and with lower fecundity and longevity. During the subsequent generation, the disease manifested itself again, probably caused by means of transovogenic transmission, which is common in other species of the genus Vairimorpha (Steinhaus, 1963; Brooks, 1968).

\section{Histopathology:}

\section{A. Mid-gut:}

The mid-gut of $S$. frugiperda larvae presented the first site of histological alterations caused by $V$. necatrix. During the initial stage of infection, the peritrophic membrane appeared to be partially ruptured. The invasion of the pathogen provoked certain characteristic abnormalities in the epithelial cells, including the grouping of these cells in variable numbers. Separation and

FIGS. $1-7-$ Histological alterations in tissues of $S$. frugiperda larvae: 1, Cross section showing a migration of $V$. necatrix from the mid-gut to the body cavity; 2, Highly infected adipose tissue; 3, Adipose tissue (not infected) in diseased larvae; 4, Agglomerations of $V$. necatrix spores in a smear of infected adipose tissues; 5 , Cross section of a nerve ganglion in diseased larvae; 6 , Cross section of a muscle in diseased larvae; 7 , Integument of a diseased larva. 
Vol. 5(4), 1988
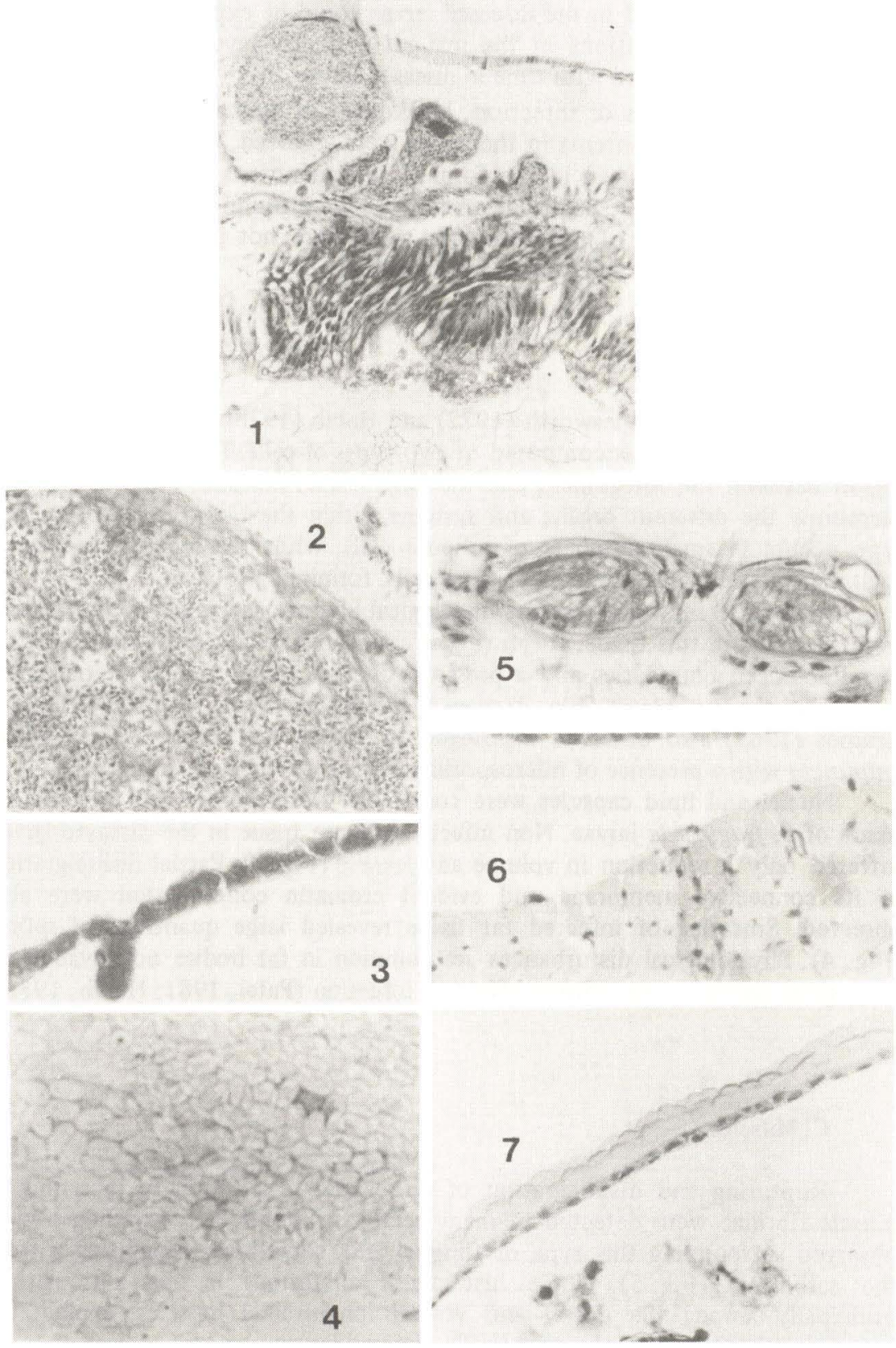

595 
displacement of circular muscles (fig. 1) from the rest of the intestine wall, vacuolization and disintegration of the epithelial cytoplasm, and beginning of cromatin condensation in the nucleus were also observed. The lack of appetite or the retention of food in the diseased larvae could be explained as a result of these histological alterations in the mid-gut epithelial layer. The intensity of these symptoms increased with time in diseased larvae.

During late stages of infection, breakdown of epithelial boundaries and scattering of the cell contents in the lumen were observed. The migration of the pathogen probably occured in the form of agglomerations, from the epithelial cells to the body cavity. Such agglomerations were found to be enveloped by some host tissues (Fig. 1). Regenerative cells were not observed in infected intestine, indicating lack of regenerative capacity.

\section{B. Adipose tissue:}

According to Wigglesworth (1972) and Habib (1978b), the adipose tissue in lepidopterous larvae is composed of two types of cells. The first occupies the region between the integument and the longitudinal muscles, while the second surrounds the different organs and systems within the body cavity. The first type occurs in small numbers of adipose cells, while the second consists of agglomerations in large numbers of these cells, forming fat bodies.

In the present work, various histological alterations caused by $V$. necatrix were observed in this tissue. Rupturing of connective membranes, disintegration of adipose cell boundaries and a presence of large quantities of the pathogen occupying the cytoplasm (Fig. 2) were the most important features. Similarly, Kramer (1965) also observed disintegration among fat bodies of Pseudaletia unipuncta with a presence of microsporidian spores of Nosema necatrix.

Nuclei and lipid capsules were completely destroyed in the infected fat tissue of $S$. frugiperda larvae. Non infected adipose tissue in the diseased larvae suffered only a reduction in volume and leaness (Fig. 3). Partial disintegration of its connective membrane and evident cromatin condensation were also observed. Smearing of infected fat tissue revealed large quantities of spores (Fig. 4). Physiological disturbances are common in fat bodies not invaded by etiological agents, as an indirect effect of infection (Patel, 1981; Habib, 1983).

\section{Muscles:}

Rupturing and disintegration of sarcolema, in addition to loosening of muscle fibrillae were detected in many sections. Spores of the pathogen were observed surrounding this type of fibrillae and, sometimes, separating it from the sarcolema (Fig. 5). These histological alterations in the musculature, principally among the dorsal and ventral longitudinal muscles, explain the reason for the flaccidity observed in the diseased larvae. 
Vol. 5(4), 1988

\section{Nerve ganglia:}

The histological alterations observed in the nervous system of $S$. frugiperda larvae infected by $V$. necatrix, probably developed as an indirect effect of the disease, as a result of some physiochemical disturbances; since the pathogen was not observed invading the tissues of this system.

Disintegration of neurolema, separation between the larval and imaginal nerve cells, and condensation of cromatin were the most evident symptoms (Fig. 6). The neuropile masses presented only a weak dissociation.

\section{E. Epidermis:}

The integument epithelial cells suffered pronounced alterations, like reduction in cytoplasm volume, disintegration of cell boundaries and cromatin condensation (Fig. 7). These alterations could explain the transparency of the integument and the facility to visualize the agglomerated patches of the infected adipose tissue. The cuticular layers remained without any injury.

\section{REFERENCES}

Brooks, W.M. 1968. Transovarian transmission of Nosema heliothidis in the corn earworm, Heliothis zea. J. Invertebr. Pathol., 11:510-512.

Habib, ME.M. 1978a. A bacterial disease of the American cotton leafworm, Alabama argillacea (Hübner, 1818) (Lepid., Noctuidae), with notes on its histological effects. $\mathbf{Z}$. ang. Ent., $85: 76-81$.

Habib, ME.M. 1978b. Anatomy and histology of the mature larva of the American cotton leafworm, Alabama argillacea (Hübner, 1818). Anais da S.E.B., 7:7-14.

Habib, M.E.M. 1983. Potency of Bacillus thuringiensis var. israelensis (H-14) against some aquatic dipterous insects. $\mathbf{Z}$. ang. Ent., 95:368-376.

Kramer, J.P. 1965. Nosema necatrix sp. n. and Thelohania diazoma sp.n. microsporidians from the armyworm Pseudaletia unipunctata (Haworth). J. Invertebr. Pathol., 7:117121.

Maddox, J.V. 1968. Generation time of the microsporidian, Nosema necatrix, in larvae of the armyworm, Pseudaletia unipunctata. J. Invertebr. Pathol., 11:90-96.

Patel, P.N. 1981. Estudos de fatores bióticos de controle natural em populações de Spodoptera frugiperda (Lepidoptera, Noctuidae). Campinas, 98pp. Tese de Mestrado, UNICAMP.

Pilley, B.M. 1976. A new genus, Vairimorpha (Protozoa: Microsporidae) for Nosema necatrix Kramer, 1965: Pathogenicity and life cycle in Spodoptera exempta (Lepidoptera: Noctuidae). J. Invertebr. Pathol., 28:177-183. 
Revta bras. Zool.

Steinhaus, E.A. Insect Pathology. An advanced treatise. Vol. 1, 661 pp; Vol. 2, 689pp. Academic Press, New York \& London.

Tanada, Y. \& G.Y. Chang. 1962. An epizootic resulting from microsporidian and two virus infections in the armyworm, Pseudaletia unipunctata (Haworth). J. Invertebr. Pathol., 4:129-131.

Wigglesworth, V.B. 1972. The principles of Insect Physiology. 7th edition, Chapman \& Hall, London, 795 pp. 